\title{
EVALUATION AND USE OF FINANCIAL RATIOS IN ASSESSING MANAGEMENT EXCELLENCE
}

\author{
Beverly L. Little \\ Department of Business Administration \\ Northwestern Louisiana University \\ Natchitoches, Louisiana
}

\section{Introduction}

In their 1982 best-seller, In Search of Excellence, Thomas J. Peters and Robert H. Waterman, Jr. identify a number of American companies which exemplify excellence in management. Their research was extensive, encompassing months of personal interviews and on-sight exploration. From this research, eight attributes emerged as characterizing the most innovative, excellently-managed companies: a bias for action; closeness to the customer; autonomy and entrepreneurship; productivity through people; hands-on, value-driven philosophy (the now-famous Management by Wandering Around); sticking to the knitting; simple form, lean staff; and simultaneous loose-tight properties.

Innovation is not an end itself, but a means to success. Therefore, in order to be included in the final list a company had to meet certain financial criteria. An excellent company had to have been in the top half of its industry in four of six standards: three measures of growth (compound asset growth, compound equity growth, and ratio of market price to book price) and three measures of return on capital (average return on capital, average return on equity, average return on sales) over the twenty-year period 1961-1980 (5).

\section{Purpose of the Study}

The value of analysis of accounting information in judging the performance of a company is generally accepted in the financial community. The purpose of this study was to examine the companies deemed as excellent in light of recent accounting data to determine if the claim of excellence was confirmed. The hypothesis was that the results of the analyses performed would support the contention of excellence, and thereby, substantiate the value of accounting analysis as a tool for the evaluation of the management of a business enterprise. 


\section{Methodology}

From Peters and Waterman's final list of fourteen, data was available though COMPUSTAT for thirteen: Boeing, Caterpillar, Dana, Delta Airlines, Digital, Emerson Electric, Fluor, Hewlett-Packard, IBM, Johnson and Johnson, McDonald's, Proctor \& Gamble, and 3M. (Bechtel was not available). Regular financial statements, common-size financial statements, and financial ratios for these thirteen firms and their corresponding industries were generated by COMPUSTAT for the five most recent years available, 19781982. The companies themselves were excluded from the industry composit$e$; in cases when more than one of the firms were in the same industry (Hewlett-Packard, IBM, and Digital; and Johnson and Johnson, and 3M) each was compared to a composite from which all were excluded. A list of the companies used in compiling the industry composite figures is provided in Appendix A.

The measures selected for analysis in this study were five of the most widely-reported and standard ratios: acid-test ratio, debt to asset ratio, inventory turnover, accounts receivable turnover, and return on investment. These represent the basic areas of liquidity, leverage, activity, and profitability. Each of the ratios will be treated separately. The focus of this analysis was to assess the performance of each company over the five-year period and to compare each company with composite ratios for its industry.

\section{Analysis of Ratios}

\section{Acid-Test Ratio}

The acid-test ratio is a measure of a firm's liquidity based on those assets most quickly convertible into cash. It shows the relationship of a firm's cash, cash equivalents, and accounts receivable to its current liabilities. It is a sterner test of liquidity than is the current ratio (current assets/current liabilities) because it does not include inventory. The exclusion of inventory relieves the ratio of any distortion due to variations in inventory accounting methods but also discounts the liquidity of fast-turning inventory $(1$, p. 72$)$.

As can be seen from Table 1, no distinct pattern emerges that allows the analyst to conclude excellence on the basis of liquidity. The only similarity is the presence of wider swings in the company's ratio than in that of its industry. Boeing Company and Caterpillar maintained higher average acidtest ratios than did their industries, but experienced wider swings. McDonald's and Johnson and Johnson experienced wider swings than did the industry, but maintained lower averages. Proctor and Gamble, Dana, Fluor, Delta and 3M maintained lower acid-test ratios than did their industries. IBM, Hewlett-Packard, Digital, and Emerson, maintained higher acid-test ratios than did their industries. 


\section{Table 1}

Acid-Test Ratio

1978-1982

\begin{tabular}{|c|c|c|c|}
\hline & High & Low & Average \\
\hline IBM & 1.41 & .93 & 1.15 \\
\hline H-P & 1.69 & 1.23 & 1.38 \\
\hline Digital & 2.95 & 2.25 & 2.49 \\
\hline Industry & .91 & .82 & .86 \\
\hline Dana & .95 & .80 & .87 \\
\hline Industry & 1.11 & .89 & 1.04 \\
\hline Delta & .82 & .53 & .63 \\
\hline Industry & .97 & .59 & .75 \\
\hline Emerson & 1.10 & 1.00 & 1.04 \\
\hline Industry & .91 & .82 & .86 \\
\hline Fluor & 1.03 & .65 & .87 \\
\hline Industry & 1.31 & 1.12 & 1.19 \\
\hline J\&J & 1.86 & 1.25 & 1.43 \\
\hline $3 \mathrm{M}$ & 1.46 & 1.03 & 1.20 \\
\hline Industry & 1.83 & 1.40 & 1.51 \\
\hline McDonald's & .82 & .33 & .55 \\
\hline Industry & .77 & .70 & .74 \\
\hline Boeing & 1.23 & .24 & .73 \\
\hline Industry & .67 & .51 & .58 \\
\hline Caterpillar & 1.15 & .45 & .72 \\
\hline Industry & .79 & .50 & .67 \\
\hline P\&G & 1.14 & .75 & .89 \\
\hline Industry & 1.35 & 1.14 & 1.24 \\
\hline
\end{tabular}

\section{Debt to Assset Ratio}

The ratio of total debt to total assets is a measure of the percentage of total funds provided by creditors (financial leverage). This ratio is of interest to owners, who may wish to limit their investment by augmenting it with debt, 
but who do not want their control of the company to be overly diluted. Potential creditors are concerned with the level of owner investment and a firm's ability to meet its liabilities. Incurring debt requires a fixed payment of interest charges. Accompanying sales growth in excess of that required to meet such fixed charges can magnify earnings. Therefore, the debt/asset ratio should be evaluated in conjunction with a profitability measure $(6, p$. 140).

\begin{tabular}{|c|c|c|c|}
\hline \multicolumn{4}{|c|}{$\begin{array}{c}\text { Table } 2 \\
\text { Total Debt/Total Assets } \\
\text { 1978-1982 }\end{array}$} \\
\hline & High & Low & Average \\
\hline IBM & .12 & .03 & .09 \\
\hline $\mathrm{H}-\mathrm{P}$ & .09 & .06 & .07 \\
\hline Digital & .03 & .19 & .13 \\
\hline Industry & .27 & .22 & .24 \\
\hline Dana & .26 & .19 & .23 \\
\hline Industry & .24 & .21 & .22 \\
\hline Delta & .24 & .10 & .13 \\
\hline Industry & .53 & .41 & .46 \\
\hline Emerson & .15 & .08 & .11 \\
\hline Industry & .13 & .11 & .12 \\
\hline Fluor & .26 & .18 & .13 \\
\hline Industry & .36 & .26 & .31 \\
\hline$J \& J$ & .08 & .04 & .07 \\
\hline $3 \mathrm{M}$ & .12 & .09 & .11 \\
\hline Industry & .22 & .19 & .21 \\
\hline McDonald's & .44 & .35 & .40 \\
\hline Industry & .34 & .30 & .32 \\
\hline Boeing & .06 & .02 & .04 \\
\hline Industry & .13 & .06 & .10 \\
\hline Caterpillar & .36 & .23 & .27 \\
\hline Industry & .26 & .20 & .22 \\
\hline P\&G & .17 & .14 & .15 \\
\hline Industry & .27 & .17 & .23 \\
\hline
\end{tabular}


As can be seen in Table 2, ten of the companies, IBM, Hewlett-Packard, Digital, Delta, Emerson, Fluor, Johnson and Johnson, 3M, Boeing, and Proctor and Gamble maintained debt/asset ratios lower in every case than those of their respective industries. Dana experienced wider swings then did their industry, and averaged about the same. Caterpillar and McDonald's maintained debt/asset ratios higher in every case than those of their composite industries. While the average debt ratios ranged from .04 for Boeing to .40 for McDonald's, it can be seen that most of the excellent companies' use of debt is less than that of their competitors.

\section{Inventory Turnover}

Inventory turnover (cost of goods sold/average inventory) is a measure of the speed with which inventories move through the business. This ratio is of significance because inventory represents an investment for the purpose of making a profit. It would appear that the faster a business turns its inventory the better, but this is true only to a point. A high turnover should not be achieved at the expense of a low gross margin or an inventory level that is too low. On the other hand, while a firm must maintain inventory adequate to generate sales, excessive inventories require costs of storage and insurance and tie up funds that could be used otherwise $(4$, p. 52).

Table 3

Inventory Turnover

1978-1982

IBM

H-P

Digital

Industry

Dana

Industry

Delta

Industry

Emerson

Industry

Fluor

Industry
High

4.4

3.0

2.1

2.9

4.2

5.8

114.1

23.9

2.8

5.7

57.7

10.5
Low

3.3

2.4

1.8

2.8

3.3

5.4

55.0

21.4

2.5

4.9

21.0

5.4
Average

3.8

2.7

1.9

2.8

\section{7}

5.8

83.3

22.0

2.7

5.4 
McDonald's

78.1

Industry

Boeing

Industry

Caterpillar

Industry

P\&G

Industry
28.3

10.4

4.1

3.9

3.0

5.5

4.6
71.1

18.3

73.9

24.2

1.9

6.2

3.7

3.8

2.8

3.5

2.9

2.8

5.2

5.3

3.8

As can be seen in Table 3, no definite pattern emerges as to the speed with which inventory is turned over. Eight of the companies (IBM, HewlettPackard, Delta, Fluor, McDonald's, Boeing, Caterpillar, and Proctor and Gamble) turned their inventory over more rapidly than did their respective industries. Boeing's average was almost double that of its industry; Delta's was four times their industry average. McDonald's low of 71.1 compares to 18.3 for the industry. Both Johnson and Johnson and $3 \mathrm{M}$ turned their inventory more slowly then did their industry; Digital, Emerson, and Dana also underperformed their industries in turnover of inventory.

\section{Accounts Receivable Turnover}

For any firm which sells largely on credit, accounts receivable are a significant source of working capital. Accounts receivable turnover is a measure of the speed with which accounts receivable are turned into cash. It is related directly to the firm's credit policies, which should be loose enough to encourage sales but tight enough to avoid losses through uncollectibles. Assuming an appropriate credit policy, the more times per year receivables are turned, the better the cash flow (1).

Table 4

Accounts Receivable Turnover

1978-1982

IBM

High

H-P

Digital

Industry
6.7

5.8

5.0

4.8
Low

5.2

5.4

4.1

4.4
Average

5.8

5.6

4.4

4.6 


\begin{tabular}{lrrr} 
Dana & 9.4 & 6.6 & 7.7 \\
Industry & 7.6 & 7.0 & 7.5 \\
Delta & 12.6 & 10.6 & 11.7 \\
Industry & 9.7 & 8.5 & 8.8 \\
Emerson & & & \\
Industry & 7.5 & 6.7 & 6.8 \\
& 5.8 & 5.5 & 5.6 \\
Fluor & & & \\
Industry & 10.1 & 8.4 & 9.2 \\
& 7.2 & 4.7 & 5.8 \\
J\&J & & & \\
3M & 8.2 & 7.9 & 8.0 \\
Industry & 6.1 & 5.8 & 5.9 \\
& 7.2 & 6.8 & 6.9 \\
McDonald's & & & \\
Industry & 36.2 & 33.1 & 35.9 \\
& 18.0 & 16.2 & 16.7 \\
Boeing & & & \\
Industry & 18.9 & 13.6 & 16.8 \\
Caterpillar & 8.9 & 8.2 & 8.6 \\
Industry & & & \\
& 10.7 & 5.6 & 9.3 \\
P\&G & 11.4 & 7.4 & 9.4 \\
Industry & & 13.7 & 14.1 \\
\hline
\end{tabular}

A definite pattern emerges from Table 4. Ten of the thirteen companies, (IBM, Hewlett-Packard, Dana, Delta, Emerson, Fluor, Johnson and Johnson, Boeing, Proctor and Gamble, and McDonald's) exceeded their industries' accounts receivable turnovers, and Caterpillar averaged only slightly below its industry. Only Digital and 3M were consistently below their industries. It could be said with some degree of certainty that excellently managed companies collect their accounts receivable more rapidly than do their industries.

\section{Return on Investment}

The measures of liquidity, leverage, and activity used above reveal specific things about a firm, but measures of profitability show the end result of management's decisions. In a 1982 survey funded by Deloitte, Haskins and Sells, profitability ratios were rated as the most important by financial 
executives (2). The measure of profitability examined herein was return on investment (net income/total assets).

\begin{tabular}{|c|c|c|c|}
\hline & \multicolumn{2}{|c|}{$\begin{array}{c}\text { Table } 5 \\
\text { Return on Investment } \\
\text { 1978-1982 }\end{array}$} & \multirow[b]{2}{*}{ Average } \\
\hline & High & Low & \\
\hline IBM & .15 & .11 & .13 \\
\hline $\mathrm{H}-\mathrm{P}$ & .12 & .11 & .11 \\
\hline Digital & .11 & .09 & .10 \\
\hline Industry & .06 & .04 & .05 \\
\hline Dana & .10 & .03 & .07 \\
\hline Industry & .07 & .03 & .05 \\
\hline Delta & .08 & .01 & .05 \\
\hline Industry & .05 & -.02 & .007 \\
\hline Emerson & .13 & .12 & .13 \\
\hline Industry & .08 & .06 & .07 \\
\hline Fluor & .08 & .03 & .06 \\
\hline Industry & .09 & .07 & .08 \\
\hline $\mathrm{J} \& \mathrm{~J}$ & .13 & .12 & .12 \\
\hline $3 \mathrm{M}$ & .14 & .11 & .13 \\
\hline Industry & .09 & .08 & .08 \\
\hline McDonald's & .09 & .08 & .08 \\
\hline Industry & .06 & .05 & .06 \\
\hline Boeing & .10 & .04 & .08 \\
\hline Industry & .07 & .03 & .05 \\
\hline Caterpillar & .08 & -.03 & .05 \\
\hline Industry & .08 & -.12 & .02 \\
\hline P\&G & .10 & .10 & .10 \\
\hline Industry & .08 & .08 & .08 \\
\hline
\end{tabular}

As can be seen from Table 5, twelve of the companies' return on investment exceeded that of its industry, with only Fluor underperforming its industry. Caterpillar's return on investment of -.03 in 1982 compares favorably to the -.12 composite figure for the industry. The largest margins 
of outperformance were by IBM, Hewlett-Packard, Digital, and Emerson.

The return on investment ratios for these excellently managed companies roughly parallel their industry, but are consistently above. Referring to Table 2, it is noteworthy that IBM, Digital, Hewlett-Packard, Delta, Emerson, Johnson and Johnson, 3M, Boeing, and Proctor and Gamble maintained higher returns on investment with lower levels of financial leverage than did their industries.

\section{Summary and Conclusions}

It appears from this study that the analysis of financial ratios generally backs up the contention of excellent management for the five companies examined. This is not to say that in every case the company outperformed its industry, but in terms of accounts receivable turnover, debt/asset ratios, and return on investment (and in general, inventory turnover) the comparisons were favorable.

Ratio analysis is a useful tool of financial analysis, but the user should be aware of its limitations. A particular ratio should not be taken out of context, that is, viewed independently of its relation to other information about the company, the industry, or even the economy as a whole. But in such a comparison there arises another major weakness of ratios, the inconsistency of their computations $(3$, p. 78$)$. One choosing to compare companies based on ratios should be sure those ratios were computed using similar bases. One means of countering this is to obtain all the ratios under consideration from one source.

Despite these weaknesses, ratios are valuable. They provide an inexpensive, easily obtained means of analysis for the average investor or analyst. Studies such as Peters and Waterman's provide excellent in-depth information, but they are impractical or impossible for most people. When viewed from a cost/benefit perspective, financial ratios provide starting points from which more detailed study can be done.

\section{APPENDIX A}

\section{COMPANIES INCLUDED IN INDUSTRY COMPOSITES}

IBM, et al.

Burroughs

Control Data

NCR

Pitney-Bowes

Speed-O-Print

Xerox

Aeroflex Labs

Conrac

General Electric
Dana

Arrow Automotive

Arvin Industries

Borg-Warner

Donaldson

Dynalectron

Echlin

Fruehauf

Facet Enterprises

Hastings Mfg.

Kysor

Raymark
Delta

AMR Corp-Del

Alaska Airlines

Aloha, Inc.

Eastern Air Lines

Frontier Holdings

Hawaiian Airlines

KLM Royal

Muse Air

Northwest Airlines

Ozark Airlines

PSA 
Litton

N.A. Philips

Tractor

Westinghouse

\section{Caterpillar}

Allis-Chambers

Am. Hoist and Derrick

Bucyrus-Erie

CMI

Clark Equipment

Pengo

Proctor \& Gamble

Clorox

Colgate-Palmolive

Economic Laboratory

$\mathrm{NCH}$

Oaklite

Stephan Chemical

\section{$\mathrm{J} \& \mathrm{~J}, \mathbf{3 M}$}

Am. Controlled Ind.

Bemis Co.

Dennison

IPCO

Papercraft

Rexham

Tambrands

Technical Tape

Tranzonic
Standard Products

Superior Products

Transway

Wynn's

Boeing

Bangor Punta

Cessna

Glatfelter

General Dynamics

Grumman

McDonnel Douglas

\section{Fluor}

AMCA Int.

Alpha Portland

Banister Cont.

Elgin

Foster Wheeler

Great Lakes

Halliburton

McDowell Ent.

Morrison-Knudson

L.E. Myers Group

Perini
Pan Am

Piedmont Aviation

Republic Airlines

Texas Air

Tiger

TWA

UAL

USAIR

Western Airlines

World Airways

\section{McDonald's}

ARA Services

Carrol's Devl.

Church's

Collins

Denny's

Frisch's

Helm Resources

Kapok Tree Inns

Marriott

Pizza Inn

Ponderosa

Restaurant Assoc.

SAGA Corp.

\section{REFERENCES}

1. Bernstein, Leopold A., The Analysis of Financial Statements Homewood, Illinois: Dow Jones-Irwin, 1978.

2. Gibson, Charles H., "How Industry Perceives Financial Ratios," Management Accounting, (April, 1982): 13.

3. Gibson, Charles H., "The Need for Disclosure of Uniform Financial Ratios," The Journal of Accountancy, (May, 1980): 78.

4. Helfert, Erich A., Techniques of Financial Analysis Homewood, Illinois: Dow Jones-Irwin, 1972.

5. Investors Management Sciences, Inc., Compustat Englewood, CO: McGraw-Hill Company.

6. Peters, Thomas J., and Robert H. Waterman, Jr. In Search of Excellence New York: Harper and Row, 1982.

7. Weston, J. Fred, and Eugene F. Brigham, Managerial Finance Hinsdale, Illinois: The Dryden Press, 1981. 